\title{
Flowering and Fruiting Behaviour of Some Guava Genotypes under East and South East Coastal Plain Zone of Odisha, India
}

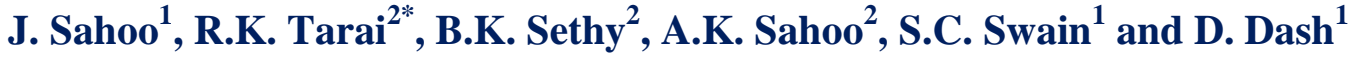 \\ ${ }^{1}$ Department of Fruit Science, College of Agriculture, Orissa University of Agriculture \\ and Technology, Bhubaneswar, Odisha, India \\ ${ }^{2}$ College of Horticulture, Chiplima, Orissa University of Agriculture and \\ Technology-768025, Odisha, India \\ *Corresponding author
}

\section{A B S T R A C T}

The flowering and fruiting behaviour of eight guava genotypes viz. Hisar Safeda, Pant Prabhat, Shweta, Hisar Surkha, L-49, Banaras Round, Allahabad Safeda and HRS Pride were studied at Horticultural Research Station, Orissa University of Agriculture and Technology, Bhubaneswar in both rainy and winter season during 2015-16 and 201617.During rainy season (Ambe bahar crop), flowering occurred during the period from $3^{\text {rd }}$ week of February to $1^{\text {st }}$ week of May (for 44 to 51 days) while during winter season (Mrig bahar crop) it was seen during the period from $2^{\text {nd }}$ week of July to $3^{\text {rd }}$ week of September

\section{Keywords}

Flowering, Fruit set, Maturity, Drop, Yield, Guava, Genotypes.

\section{Article Info}

Accepted:

28 September 2017

Available Online:

10 November 2017 (for 48 to 52 days). In both the season, Hisar Surkha took shortest days for attainment of flower bud development (27 to 32 days) while longest duration for flower bud development was recorded in Banaras Round (36 days) during rainy season and HRS Pride (40 days) during rainy season. The shortest period from flowering to fruit maturity was recorded in Hisar Surkha (during rainy season) and L-49(during winter season), while it was recorded longest in Pant Prabhat during both the season. The final fruit retention percentage was found maximum in Pant Prabhat $(67.00 \%)$ during rainy season and Shweta $(60.67 \%)$ during winter season. The fruit weight was found maximum in Pant Prabhat (147.63 g during rainy and $150.60 \mathrm{~g}$ during winter season) and minimum in Banaras Round (106.73 g during rainy season and $112.37 \mathrm{~g}$ in Hisar Safeda). The number of fruits per plant varied significantly and was recorded highest in Pant Prabhat (99.00) and Shweta (96.00) and lowest in Allahabad Safeda (52.00) and Hisar Surkha (39.67) during rainy and winter season respectively. The yield per plant varied significantly and recorded maximum in Pant Prabhat $(14.67 \mathrm{~kg})$ during rainy season and in Shweta (13.98 $\mathrm{kg}$ ) during winter. During rainy season, highest yield was found in Pant Prabhat (58.68 $\mathrm{q} / \mathrm{ha}$ ) and it was observed lowest in Allahabad Safeda (22.47 q/ha) during rainy season. During winter season Shweta (55.90 q/ha) and Hisar Surkha (15.63 q/ha) were assessed to be highest and lowest yielder respectively.

\section{Introduction}

Guava (Psidium guajava L.) belonging to family Myrtaceae is believed to be originated in Central America and the southern part of Mexico. At present, it is the fifth most important fruit crops in India after mango, banana, citrus and apple. It has been in cultivation in India since early $17^{\text {th }}$ century and gradually became a crop of commercial 
importance. Both ripe and green fruits, leaves, roots and bark are used in local medicine for treatment of gastroenteritis, diarrhea and dysentery. In guava, it has been observed that the flowering season does vary from region to region. Guava crop bears twice a year i.e., during rainy season and winter season. The quality of the guava fruit is observed to be better in winter season (Rathore, 1976). In Northern India, guava bears fruit twice a year but in Maharashtra and Tamil Nadu guava sets fruits thrice a year. Knowledge of floral morphology, blossom biology, mode of pollination, fruit set and drop is an essential pre requisite for hybridization and any fruit crop improvement programme.

It was found that fruit yield were maximum during the rainy season while fruit quality characteristics were higher during winter as compared to the rainy season (Aulakh, 2004). Selection of varieties suited to a specific climatic condition on the basis of flowering, fruit set, maturity and yield is very important to make guava cultivation economically viable. Therefore, the present investigation was conducted to find out the suitability of newly evolved varieties of guava for growing under Bhubaneswar condition.

\section{Materials and Methods}

The field experiment on " Flowering and Fruiting Behaviour of Some Guava Genotypes under East and South East Coastal Plain Zone of Odisha" during rainy and winter season under Bhubaneswar condition" was carried out during 2015-16 and 20162017 at the Horticultural Research Station, Odisha University of Agriculture and Technology, Bhubaneswar. The soil of experimental site has sandy loam texture. The place is characterized by warm and moist climate with hot and humid summer and mild winter. The experiment was conducted in Randomized block design (RBD) with 8 treatments (cultivars) and 3 replications. The plants were 5 years old and layers were planted in Horticulture Research Station, Baramunda, OUAT, Bhubaneswar on 16-72011 at a spacing of $5 \times 5$ meter. In each replication normal recommended cultural practices were followed during the course of investigation. There were eight varieties consisting of elite guava selections and hybrids viz. $\mathrm{T}_{1}$-Hissar Safeda, $\mathrm{T}_{2}$-Pant Prabhat, $\mathrm{T}_{3}$-Shweta, $\mathrm{T}_{4}$-Hissar Surkha, $\mathrm{T}_{5}$-L49, $\mathrm{T}_{6}-$ Banaras Round, $\mathrm{T}_{7}-$ Allahabad Safeda and $\mathrm{T}_{8^{-}}$HRS Pride. The observations on flowering behavior, fruit set, fruit drop, fruit retention, fruit maturity and yield were recorded in two seasons i.e. for ambe bahar (rainy season) and mrig bahar (winter season) crop of guava.

\section{Flower bud development}

The period required from initiation of flower bud to its opening is known as period required for flower bud development. Around 20 number of flower buds were tagged soon after its emergence for recording the above parameter during both ambe and mrig bahar crop.

\section{Date of first flowering}

Appearance of 20 number of flowers in a particular date during initial phase of flowering during rainy and winter season was recorded as the date of first flowering.

\section{Date of full blossom}

Appearance of maximum number of flowers during both ambe (rainy season) and mrig (winter season) bahar crop in a particular period was recorded as the date of full blossom.

\section{Date of end of flowering}

Appearance of 20 number of flowers in a particular date towards last phase of flowering 
during rainy and winter season was recorded as the date of end of flowering.

\section{Duration of flowering (days)}

The period between date of first flowering and date of last flowering is known as duration of flowering. The observation was taken for both rainy and winter season crop.

\section{Time required from flowering to} harvesting

It is the number of days counted from fruit setting to ripening of the fruit for quality analysis at firm ripe stage.

Around 200 numbers of just opened flowers were tagged for taking this observation.

\section{Number of fruits per tree}

The numbers of fruits were taken during both the rainy and winter season by counting at maturity stage just before harvesting.

\section{Yield per tree}

The average fruit yield per plant was calculated by multiplying the total number of fruits per tree with the average fruit weight and was expressed in kilogram per tree.

Yield per tree $=$ Total number of fruits per plant $\times$ Average weight of the fruit

\section{Fruit set (\%)}

Fruit set on three marked branches was calculated as per the method suggested by Westwood (1993 b).

The data were taken during both ambe (rainy season) and mrig bahar (winter season) crop by tagging 50 number of flowers. The fruit set data were taken at 15 days after anthesis.
Fruit set $(\%)=\frac{\text { Number of fruit set }}{\text { Number of flower }} \times 100$

\section{Fruit drop (\%)}

The fruit drop \% was taken by tagging 200 number of just setted fruits and the data were recorded at mature stage during both the season. Fruit drop was calculated as per the method suggested by Westwood (1993 b) mentioned below.

Fruit drop $\quad(\%)=$ Total number of dropped fruits

Total number fruits set $\quad$ X100

The fruit of each plant were weighed separately by top pan balance and recorded at each picking. The yield per plant was recorded in kilogram $(\mathrm{kg})$ from the total harvested fruits. The analysis and interpretation of data were done using the method of Panse and Sukhatme (1989) in randomized block design.

\section{Results and Discussion}

\section{Flowering characters}

The information on time and duration of flowering is pre requisite for taking up a programme for improvement of crop through hybridization. Depending upon the environmental set up, the time and duration of flowering have been reported to be variable at different locations.

\section{Date of first flowering}

It is clear from the Table 1, that during rainy season (Ambe bahar crop), Hisar Surkha was the first to flower ( $3^{\text {rd }}$ week of February) followed by Pant Prabhat, Sweta, L-49 and Allahabad Safeda ( ${ }^{\text {th }}$ week of February) and Hisar Safeda ( $1^{\text {st }}$ week of March). Banaras 
Round and HRS Pride were last to flower $\left(2^{\text {nd }}\right.$ week of March) during rainy season. During winter season (Mrig bahar crop), Pant Prabhat ( $2^{\text {nd }}$ week of July) was first to flower followed by Hisar Safeda, Hisar Surkha and L-49 (3 ${ }^{\text {rd }}$ week of July) whereas Sweta, Banaras Round, Allahabad Safeda and HRS Pride were last to flower $\left(4^{\text {th }}\right.$ week of July) during winter season.

\section{Date of full blossom}

During rainy season the period of full blossom in different guava cultivars were between $3^{\text {rd }}$ week of March (Pant Prabhat, Hisar Surkha, L-49 and Allahabad Safeda) to $2^{\text {nd }}$ week of April (Hisar Safeda and HRS Pride) (Table 1). In cultivars like Sweta and Hisar Safeda, full blossom occurred during $4^{\text {th }}$ week of March. However, during winter season (Mrig bahar crop), the full blossom occurred during the period between $1^{\text {st }}$ week of August (L-49) to $3^{\text {rd }}$ week of August (Banaras Round and Allahabad Safeda).

\section{Date of end of flowering}

The data indicated in the Table 1, showed that the period of end of flowering varied from $2^{\text {nd }}$ week of April (Pant Prabhat, L-49) to $1^{\text {st }}$ week of May (Hisar Surkha, Banaras Round and HRS Pride) in Ambe bahar crop. However, during winter season, the end of flowering occurred between $1^{\text {st }}$ week of September (Hisar Safeda, Pant Prabhat, Hisar Surkha, L49) to $3^{\text {rd }}$ week of September (HRS Pride).

\section{Duration of flowering}

During rainy season (Ambe bahar) crop, the duration of flowering was longest in HRS Pride (51 days) followed by Sweta, Banaras Round and Allahabad Safeda (48 days) and shortest in L-49 and Hisar Safeda (44 days). During winter season (Mrig bahar) longest flowering duration was noticed in HRS Pride
(52 days) followed by Hisar Surkha (51 days) and Banaras Round (50 days) while, shortest flowering duration was noticed in Pant Prabhat (48 days).

During rainy season (Ambe Bahar crop), Hisar Surkha was the first to flower $\left(3^{\text {rd }}\right.$ week of February) and Banaras Round and HRS Pride were last to flower ( $2^{\text {nd }}$ week of March). During winter season (Mrig Bahar crop), Pant Prabhat ( $2^{\text {nd }}$ week of July) was first to flower while Shweta, Banaras Round, Allahabad Safeda and HRS Pride were last to flower $\left(4^{\text {th }}\right.$ week of July) during winter season. The period of end of flowering varied from $2^{\text {nd }}$ week of April (Pant Prabhat, L-49) to $1^{\text {st }}$ week of May (Hisar Surkha, Banaras Round and HRS Pride) in Ambe Bahar crop.

However, during winter season, the end of flowering occured between $1^{\text {st }}$ week of September (Hisar Safeda, Pant Prabhat, Hisar Surkha, L-49) to $3^{\text {rd }}$ week of September (HRS Pride). The duration of flowering was longest in HRS Pride (51 days) and shortest (44 days) in L-49 and Hisar Safeda during rainy season.

During winter season (Mrig Bahar) longest flowering duration was noticed in HRS Pride (52 days) and shortest in Pant Prabhat (48 days). Apart from the varietal differences, the time and duration of flowering is influenced by environmental conditions in guava (Reddy and Kurian, 2008). The duration of flowering during winter season was more than that of rainy season. This result was in close proximity with the findings of Kundu and Mitra (1994) who reported that duration of flowering in autumn for winter crop was longer than summer season flowering for rainy season crop under West Bengal condition. However, Ojha et al., (1985) reported more flowering duration during rainy season than that of winter season crop. The discrepancy may be due to change in environmental condition. 


\section{Period required for flower bud development}

From the data presented in the Table 2, it is apparent that during both the rainy and winter season, Hisar Surkha took shortest days for attainment of flower bud development (27 days during rainy season and 32 days in winter season) while longest duration for flower bud development was recorded in Banaras Round (36 days) during rainy season and HRS Pride (40 days) during winter season crop. Not much difference for time required for flower bud appearance was observed among different varieties for both the seasons during the year and it was also noticed that time of flower bud appearance varied for particular variety during the year for rainy as well as winter season.

This variation may be attributed to environmental influence on this trait. This result was in line with the finding of Singh and Sehgal (1968) who reported that guava requires 30 days from flower bud differentiation to complete the development of calyx cracking stage in North India. A little variation for this trait was observed between varieties and between the season. However, this variation may be attributed to environmental influence to this trait and also due to genetic constitution of the variety. No flowering was observed in Hasth Bahar crop during October-November.

\section{Period required from flowering to fruit maturity}

Hisar Surkha and L-49 took shortest period (124 days during rainy season and 123 days during winter season) from flowering to fruit maturity whereas longest period from flowering to fruit maturity was noticed in Pant Prabhat (134 days during rainy season and 138 days during winter season). Similar findings were observed by Deshpande (2006) who reported that the number of days from flowering to fruit maturity varied between 121.33 (cv. GR-1) and 125.93 (cv. CIW- 5) in an evaluation study conducted by under Arabhavi conditions. However, Milan (2007) observed that the period from flowering to fruit maturity varied between 105 days to 124 days.

\section{Fruit set (\%) at 15 days after anthesis}

During winter season crop there was no significant differences with respect to the percentage of fruit set at 15 days after anthesis was observed. It was found maximum in Pant Prabhat (73.67 \%) followed by L-49 (73.00 \%), HRS Pride (72.67 \%) and Banaras Round $(69.33 \%)$, while the minimum percentage of fruit set was observed in Hisar Surkha $(64.00 \%)$. It was inferred from the Table 3, that there was significant differences with respect to fruit set (\%) at 15 days after anthesis during rainy season crop of guava.

During rainy season the highest fruit set (\%) at 15 days after anthesis was found in Pant Prabhat $(82.67 \%)$ followed by Shweta and HRS Pride (80.00\% each) and Allahabad Safeda $(79.00 \%)$, while it was found lowest in Hisar Surkha $(68.00 \%)$ followed by Banaras Round (74.67 \%), Hisar Safeda (76.00\%) and L-49 (77.00\%). During rainy season the varieties like Allahabad Safeda, HRS Pride, Shweta and Pant Prabhat were statistically at par with respect to fruit set (\%) at 15 days after anthesis and were significantly different from other varieties.

\section{Fruit drop (\%)}

It was quite apparent from the data presented in the Table 3, that there were significant differences in percentage of fruit drop in different cultivars during rainy season crop of guava. 
Table.1 Flowering behaviour of different cultivars of guava during both ambe and mrig bahar crop

\begin{tabular}{|c|c|c|c|c|c|c|c|c|}
\hline \multirow[t]{2}{*}{ Varieties } & \multicolumn{2}{|c|}{ Date of First Flowering } & \multicolumn{2}{|c|}{ Date of Full Blossom } & \multicolumn{2}{|c|}{ Date of End of Flowering } & \multicolumn{2}{|c|}{$\begin{array}{c}\text { Duration of flowering } \\
\text { (Days) }\end{array}$} \\
\hline & $\begin{array}{l}\text { Ambe } \\
\text { Bahar }\end{array}$ & $\begin{array}{l}\text { Mrig } \\
\text { Bahar }\end{array}$ & $\begin{array}{l}\text { Ambe } \\
\text { Bahar }\end{array}$ & $\begin{array}{c}\text { Mrig } \\
\text { Bahar }\end{array}$ & $\begin{array}{l}\text { Ambe } \\
\text { Bahar }\end{array}$ & $\begin{array}{l}\text { Mrig } \\
\text { Bahar }\end{array}$ & $\begin{array}{l}\text { Ambe } \\
\text { Bahar }\end{array}$ & $\begin{array}{l}\text { Mrig } \\
\text { Bahar }\end{array}$ \\
\hline Hisar Safeda & $\begin{array}{c}1^{\text {st }} \text { Week of } \\
\text { March }\end{array}$ & $\begin{array}{c}3^{\text {rd }} \text { Week of } \\
\text { July }\end{array}$ & $\begin{array}{c}4^{\text {th }} \text { Week of } \\
\text { March }\end{array}$ & $\begin{array}{c}2^{\text {nd }} \text { Week of } \\
\text { August }\end{array}$ & $\begin{array}{c}4^{\text {th }} \text { Week of } \\
\text { April }\end{array}$ & $\begin{array}{l}1^{\text {st }} \text { week of } \\
\text { September }\end{array}$ & 44 & 49 \\
\hline Pant Prabhat & $\begin{array}{c}4^{\text {th }} \text { Week of } \\
\text { February }\end{array}$ & $\begin{array}{c}2^{\text {nd }} \text { Week of } \\
\text { July }\end{array}$ & $\begin{array}{c}3^{\text {rd }} \text { week of } \\
\text { March }\end{array}$ & $\begin{array}{c}2^{\text {nd }} \text { Week of } \\
\text { August }\end{array}$ & $\begin{array}{c}2^{\text {nd }} \text { Week of } \\
\text { April }\end{array}$ & $\begin{array}{l}1^{\text {st }} \text { Week of } \\
\text { September }\end{array}$ & 47 & 48 \\
\hline Shweta & $\begin{array}{c}4^{\text {th }} \text { Week of } \\
\text { February }\end{array}$ & $\begin{array}{c}4^{\text {th }} \text { Week of } \\
\text { July }\end{array}$ & $\begin{array}{c}4^{\text {th }} \text { Week of } \\
\text { March }\end{array}$ & $\begin{array}{c}2^{\text {nd }} \text { Week of } \\
\text { August }\end{array}$ & $\begin{array}{c}3^{\text {rd }} \text { Week of } \\
\text { April }\end{array}$ & $\begin{array}{l}2^{\text {nd }} \text { Week of } \\
\text { September }\end{array}$ & 48 & 49 \\
\hline Hisar Surkha & $\begin{array}{c}3^{\text {rd }} \text { week of } \\
\text { February }\end{array}$ & $\begin{array}{c}3^{\text {rd }} \text { Week of } \\
\text { July }\end{array}$ & $\begin{array}{c}3^{\text {rd }} \text { Week of } \\
\text { March }\end{array}$ & $\begin{array}{c}2^{\text {nd }} \text { week of } \\
\text { August }\end{array}$ & $\begin{array}{c}1^{\text {st }} \text { Week of } \\
\text { May }\end{array}$ & $\begin{array}{l}1^{\text {st }} \text { Week of } \\
\text { September }\end{array}$ & 45 & 51 \\
\hline L-49 & $\begin{array}{c}4^{\text {th }} \text { Week of } \\
\text { February }\end{array}$ & $\begin{array}{c}3^{\text {rd }} \text { Week of } \\
\text { July }\end{array}$ & $\begin{array}{c}3^{\text {rd }} \text { Week of } \\
\text { March }\end{array}$ & $\begin{array}{c}1^{\text {st }} \text { week of } \\
\text { August }\end{array}$ & $\begin{array}{c}2^{\text {nd }} \text { Week of } \\
\text { April }\end{array}$ & $\begin{array}{l}1^{\text {st }} \text { Week of } \\
\text { September }\end{array}$ & 44 & 46 \\
\hline Banaras Round & $\begin{array}{c}2^{\text {nd }} \text { Week of } \\
\text { March }\end{array}$ & $\begin{array}{c}4^{\text {th }} \text { Week of } \\
\text { July }\end{array}$ & $\begin{array}{c}2^{\text {nd }} \text { Week of } \\
\text { April }\end{array}$ & $\begin{array}{c}3^{\text {rd }} \text { Week of } \\
\text { August }\end{array}$ & $\begin{array}{c}1^{\text {st }} \text { Week of } \\
\text { May }\end{array}$ & $\begin{array}{l}2^{\text {nd }} \text { Week of } \\
\text { September }\end{array}$ & 48 & 50 \\
\hline Allahabad Safeda & $\begin{array}{c}4^{\text {th }} \text { Week of } \\
\text { February }\end{array}$ & $\begin{array}{c}4^{\text {th }} \text { Week of } \\
\text { July }\end{array}$ & $\begin{array}{c}3^{\text {rd }} \text { Week of } \\
\text { March }\end{array}$ & $\begin{array}{c}3^{\text {rd }} \text { Week of } \\
\text { August }\end{array}$ & $\begin{array}{c}2^{\text {nd }} \text { Week of } \\
\text { April }\end{array}$ & $\begin{array}{c}2^{\text {nd }} \text { Week of } \\
\text { September }\end{array}$ & 48 & 49 \\
\hline HRS Pride & $\begin{array}{c}2^{\text {nd }} \text { Week of } \\
\text { March }\end{array}$ & $\begin{array}{c}4^{\text {th }} \text { Week of } \\
\text { July }\end{array}$ & $\begin{array}{c}2^{\text {nd }} \text { Week of } \\
\text { April }\end{array}$ & $\begin{array}{c}3^{\text {rd }} \text { Week of } \\
\text { August }\end{array}$ & $\begin{array}{c}1^{\text {st }} \text { Week of } \\
\text { May }\end{array}$ & $\begin{array}{l}3^{\text {rd }} \text { Week of } \\
\text { September }\end{array}$ & 51 & 52 \\
\hline
\end{tabular}


Table.2 Period required for flower bud development and fruit maturity in different guava cultivars during rainy and winter season

\begin{tabular}{|l|c|c|c|c|}
\hline \multirow{2}{*}{ Variety } & \multicolumn{2}{|c|}{$\begin{array}{c}\text { Period required for flower bud } \\
\text { development (Days) }\end{array}$} & \multicolumn{2}{c|}{$\begin{array}{c}\text { Period required from flowering to fruit } \\
\text { maturity (Days) }\end{array}$} \\
\cline { 2 - 5 } & RS & WS & RS & WS \\
\hline Hisar Safeda & 29.00 & 34.00 & 126.00 & 130.00 \\
\hline Pant Prabhat & 33.00 & 38.00 & 134.00 & 138.00 \\
\hline Shweta & 33.00 & 39.00 & 132.00 & 135.00 \\
\hline Hisar Surkha & 27.00 & 32.00 & 124.00 & 127.00 \\
\hline L-49 & 30.00 & 34.00 & 127.00 & 123.00 \\
\hline Banaras Round & 36.00 & 37.00 & 125.00 & 129.00 \\
\hline Allahabad Safeda & 31.00 & 35.00 & 127.00 & 131.00 \\
\hline HRS Pride & 35.00 & 40.00 & 129.00 & 131.00 \\
\hline S.E $(m) \pm$ & 0.83 & 0.94 & 1.07 & 0.54 \\
\hline CD at $(5 \%)$ & 2.42 & 2.74 & 3.14 & 1.58 \\
\hline
\end{tabular}

Table.3 Fruit set, fruit drop and fruit retention during both Rainy and Winter season crop of guava cultivars

\begin{tabular}{|c|c|c|c|c|c|c|}
\hline \multirow{2}{*}{ Varieties } & \multicolumn{2}{|c|}{$\begin{array}{c}\text { Fruit set (\%) at 15 days } \\
\text { after anthesis }\end{array}$} & \multicolumn{2}{c|}{ Fruit drop (\%) } & \multicolumn{2}{c|}{ Final fruit retention (\%) } \\
\cline { 2 - 6 } & RS & WS & RS & WS & RS & WS \\
\hline Hisar Safeda & 76.00 & 68.33 & 40.67 & 60.33 & 59.43 & 39.67 \\
\hline Pant Prabhat & 82.67 & 73.67 & 33.00 & 46.67 & 67.00 & 53.33 \\
\hline Shweta & 80.00 & 66.67 & 36.00 & 39.33 & 64.00 & 60.67 \\
\hline Hisar Surkha & 68.00 & 64.00 & 37.33 & 55.00 & 62.67 & 45.00 \\
\hline L-49 & 77.00 & 73.00 & 44.33 & 48.67 & 55.67 & 51.33 \\
\hline Banaras Round & 74.67 & 69.33 & 52.67 & 60.00 & 47.33 & 40.00 \\
\hline Allahabad Safeda & 79.00 & 68.33 & 48.33 & 49.92 & 51.67 & 50.08 \\
\hline HRS Pride & 80.00 & 72.67 & 43.67 & 51.67 & 56.33 & 48.33 \\
\hline S.E (m) \pm & 1.68 & 2.75 & 2.94 & 3.64 & 2.79 & 3.48 \\
\hline CD at (5\%) & 4.92 & NS & 8.60 & 10.65 & 8.15 & 10.20 \\
\hline
\end{tabular}

Table.4 Yield parameters of different cultivars of guava during both rainy and winter season

\begin{tabular}{|c|c|c|c|c|c|c|c|c|}
\hline \multirow{2}{*}{ Varieties } & \multicolumn{2}{|c|}{ Number of fruits per plant } & \multicolumn{2}{c|}{ Yield per plant $(\mathbf{k g})$} & \multicolumn{2}{c|}{ Yield per ha $(\mathbf{q})$} & \multicolumn{2}{c|}{ Fruit weight (g) } \\
\cline { 2 - 9 } & RS & WS & RS & WS & RS & WS & RS & WS \\
\hline Hisar Safeda & 86.33 & 44.67 & 9.75 & 4.41 & 39.00 & 17.66 & 112.97 & 112.37 \\
\hline Pant Prabhat & 99.00 & 49.33 & 14.67 & 7.42 & 58.68 & 29.69 & 147.63 & 150.60 \\
\hline Shweta & 67.33 & 96.00 & 8.17 & 13.98 & 32.66 & 55.90 & 129.17 & 145.77 \\
\hline Hisar Surkha & 61.00 & 39.67 & 7.51 & 3.91 & 30.05 & 15.63 & 123.00 & 119.80 \\
\hline L-49 & 57.00 & 42.67 & 6.65 & 5.03 & 26.61 & 20.13 & 116.63 & 134.60 \\
\hline Banaras Round & 58.00 & 40.67 & 6.19 & 4.76 & 24.77 & 19.05 & 106.73 & 112.63 \\
\hline Allahabad Safeda & 52.00 & 44.67 & 5.62 & 4.88 & 22.47 & 19.52 & 107.93 & 124.93 \\
\hline HRS Pride & 55.67 & 40.00 & 6.76 & 4.66 & 27.05 & 18.64 & 120.50 & 126.83 \\
\hline S.E (m) \pm & 2.82 & 3.15 & 0.59 & 0.51 & 2.34 & 2.05 & 4.57 & 2.68 \\
\hline CD at (5 \%) & 8.26 & 9.21 & 1.71 & 1.50 & 6.85 & 5.99 & 13.37 & 7.84 \\
\hline
\end{tabular}


Fig.1 Yield q/ha of the guava cultivars

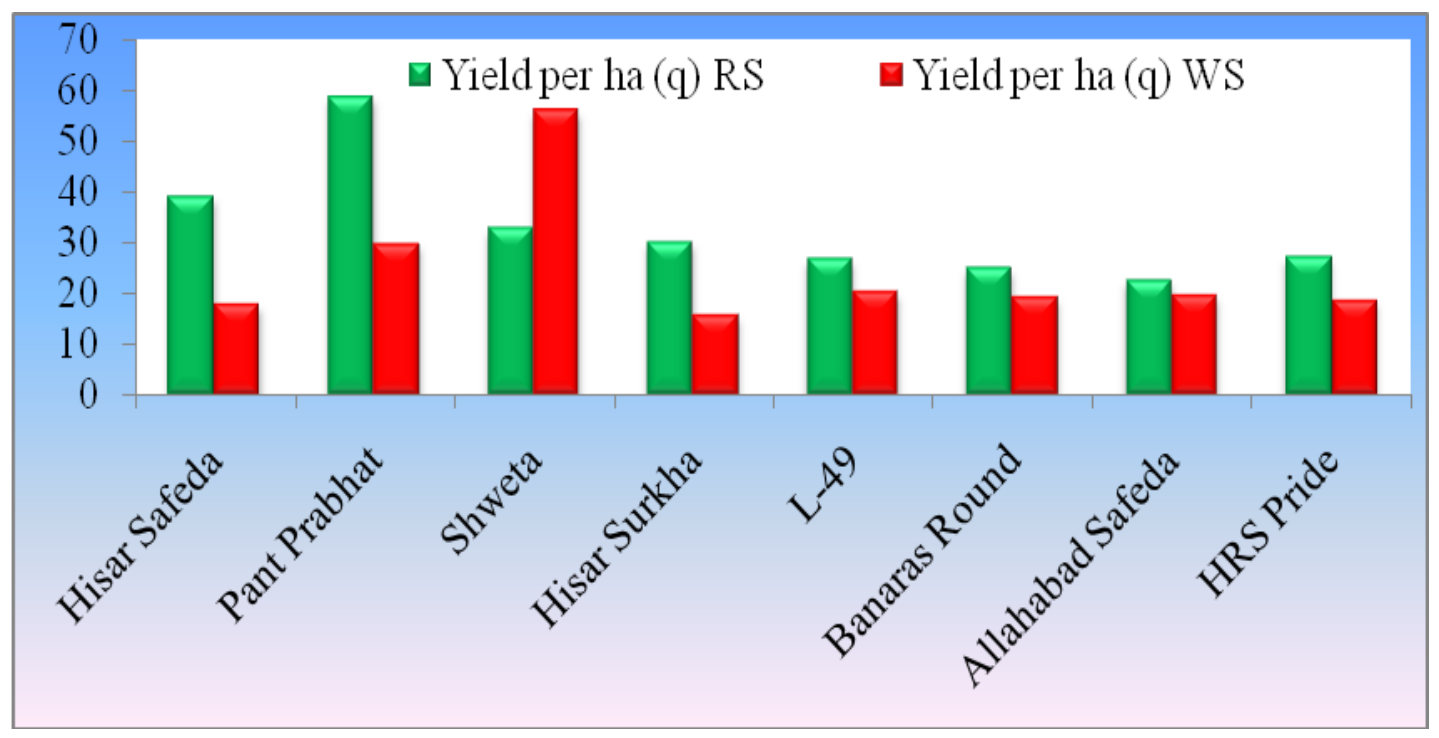

The maximum fruit drop was noticed in Banaras Round $(52.67 \%)$ followed by Allahabad Safeda (48.33\%), L-49 (44.33\%) and HRS Pride (43.67 \%), while minimum fruit drop was observed in Shweta (36.00\%) followed by Hisar Surkha (37.33 \%), Pant Prabhat $(38.33 \%)$ and Hisar Safeda (40.67 \%). The fruit drop percentage during rainy season was found highest in Banaras Round to which the varieties such as L-49, Allahabad Safeda and Banaras Round were recorded significantly at par and the varieties such as Shweta, Hisar Surkha, Pant Prabhat and Hisar Safeda were observed significantly different from Banaras Round.

The fruit drop (\%) during winter season crop of guava was slightly higher as compared to the rainy season crop and showed significant differences among the varieties with maximum fruit drop $(60.33 \%)$ in Hisar Safeda followed by Banaras Round (60.00\%), Hisar Surkha $(55.00 \%)$ and HRS Pride (51.67\%) and minimum in Shweta (39.33 \%) followed by Pant Prabhat (46.67 \%) and L-49 (48.67\%). The percentage of fruit drop in winter season was found highest in Hisar Safeda to which the varieties such as Allahabad Safeda, HRS Pride, Hisar Surkha and Banaras Round were statistically at par while the varieties such as
Shweta, Hisar Surkha, Pant Prabhat and Hisar Safeda were showing significantly different from Hisar Safeda.

\section{Final fruit retention $(\%)$}

During both rainy and winter season crop of guava varieties there is significant differences with respect to final fruit retention (\%) at maturity. The data regarding fruit retention percentage has been given in Table 3. A profuse fruit retention percentage was observed in the rainy season crop which ranged from a minimum of $47.33 \%$ in Banaras Round to a maximum of $67.00 \%$ in Pant Prabhat. The maximum fruit retention percentage during rainy season crop was observed in Pant Prabhat with $(67.00 \%)$ followed by Shweta $(64.00 \%)$, Hisar Surkha (62.67\%) and Hisar Safeda $(59.43 \%)$, while the minimum fruit retention percentage was recorded in Banaras round (47.33\%) followed by Allahabad Safeda (51.67 $\%)$, L-49 (55.67 \%) and HRS Pride (56.33\%). The highest percentage of fruit retention was recorded in Pant Prabhat to which the varieties such as Hisar Safeda, Hisar Surkha and Shweta were statistically at par whereas the varieties such as Banaras Round, Allahabad Safeda, L-49 and HRS Pride were recorded significantly different. The varieties such as Hisar Surkha, 
Shweta and Pant Prabhat were found superior over the Allahabad Safeda (check) with respect to the fruit set percentage during rainy season. During winter season the maximum fruit retention percentage was observed in Shweta (60.67\%) followed by Pant Prabhat (53.33\%), L-49 (51.33 \%) and Allahabad Safeda (50.08 $\%$ ), while minimum fruit retention percentage (39.67 \%) was observed in Hisar Safeda (39.67 $\%)$ followed by Banaras Round $(40.00 \%)$ and Hisar Surkha (45.00 \%). The sequence in which the higher fruit retention percentage recorded were Shweta (60.67\%) followed by Pant Prabhat (53.33\%), L-49 (51.33\%), Allahabad Safeda (50.08\%), HRS Pride (48.33\%), Hisar Surkha (45.00\%), Banaras Round (40.00\%) and Hisar Safeda (39.67\%). The varieties such as L-49 and Pant Prabhat were found statistically at par with Shweta while the remaining varieties were significantly different from Shweta. The variety Shweta was also found significantly superior to Allahabad Safeda (check) with respect to the fruit retention percentage in winter season.

The percentage of fruit set is directly dependent on the abundance of flowers and their existence in the trees. The highest percentage of fruit setting (15 days after anthesis) was observed in Pant Prabhat $(82.67 \%$ during rainy season and $73.67 \%$ during winter season) while Hisar Surkha showed the lowest fruit set \% $(68.00 \%$ during rainy season and $64.00 \%$ during winter season).This result was in close proximity with the findings of Dubey et al., (2004) who observed higher fruit set and retention the winter crop season as compared with other cropping season. The maximum fruit drop was observed in Banaras Round (52.67\%) while it was minimum in Shweta $(36.00 \%)$ during rainy season. During winter season maximum fruit drop $(60.33 \%)$ was recorded in Hisar Safeda and minimum $(39.33 \%)$ in Shweta. Although the fruit set is a varietal character, it also highly depends on several factors like time of flowering, sex ratio, efficient cross-pollination, intensity of fruit drop, weather condition as well as irrigation requirements.

\section{Yield and yield attributing parameter}

The yield per plant varied significantly among all the varieties studied. The number of fruits per plant also varied significantly. It was observed to be highest in Pant Prabhat (99.00) during rainy season and Shweta (96.00) during winter season. However the lowest number of fruits per plant was recorded in Allahabad Safeda (52.00) and Hisar Surkha (39.67) during both rainy and winter season respectively (Table 4). The fruit that matured during winter season attained more weight than harvested during rainy summer season. The probable cause may be that the winter season fruit set occurs during August when plenty of food material is available in comparison to fruit set in April. Apart from food materials, climatic factors such as temperature and humidity prevailing during winter season are also favourable for development of fruits. In winter season, the increased fruit weight was might be due to increase in sucrose accumulation in the pulp tissues of guava fruits. In rainy season crop the fruit weight might be decreased due to attack and damage of fruit fly. The yield per plant varied significantly and recorded maximum in Pant Prabhat $(14.67 \mathrm{~kg})$ during rainy season and in Shweta $(13.98 \mathrm{~kg})$ during winter season, whereas the minimum yield per plant was found in Allahabad Safeda $(5.62 \mathrm{~kg}$ ) and Hisar Surkha $(3.91 \mathrm{~kg})$ during rainy and winter season respectively. From the data depicted in the Table 4 and Figure 1, it is obvious that the yield per hectare in rainy season varied from a minimum of 22.47 (q/ha) to a maximum of 58.68 ( $\mathrm{q} / \mathrm{ha})$. The highest yield $(58.68 \mathrm{q} / \mathrm{ha})$ was noticed in Pant Prabhat followed by Hisar Safeda (39.00 q/ha), Shweta (32.66 q/ha) and Hisar Surkha (30.05 q/ha). The lowest yield was observed in Allahabad Safeda (22.47 q/ha) followed by Banaras Round (24.77 q/ha), L-49 (26.61 q/ha) and HRS Pride (27.05 $\mathrm{q} / \mathrm{ha}$ ). The yield per hectare during winter season was recorded highest in the variety Shweta (55.90 q) followed by Pant Prabhat (29.69 q), L-49 (20.13 q) and Allahabad Safeda (19.52 q), whereas the lowest in Hisar Surkha (15.63 q) followed by Hisar Safeda (17.66 q), 
HRS Pride (18.64 q) and Banaras Round (19.05 q). So with respect to the yield per hectare during rainy season the superiority over check variety Allahabad Safeda was observed in Hisar Surkha, Shweta, Hisar Safeda and Pant Prabhat, while during winter season it was observed in Pant Prabhat and Shweta. This result was in consonance with the findings of Ghosh et al., (2013) who obtained more yield during rainy season than winter season fruits. The variation among varieties with regards to yield per plant might be due to variable fruit size, fruit weight, genetic variability, inherent characters and climatic adaptability in a particular region which might prove an important diagnostic character for selection of germplasm for local condition. The differences in yield per tree in various cultivars of guava may be ascribed to the different fruit yielding potential of the varieties under study. In some of the cultivars though the number of fruits per plant was more, but fruit yield was not so accordingly, which may be due to distribution and diversion of available assimilates in more number of fruits.

\section{References}

Aulakh, A.K. 2004. Fruit yield and quality of six outstanding selections of guava (Psidium guajava) from the calvillocamones Region, Manico, Acta Horticulturae, 735: 25-30.

Deshpande, R.S., 2006. Varietal evaluation and influence of vermi-compost in guava, $M$. Sc. (Agri.) thesis, University of Agricultural Science, Dharwad.

Dubey, P.S., Hoda, M.N., Singh, J., Singh SK. 2004. Flowering and fruiting characters of guava varieties during rainy season fruiting, Orissa Journal of Horticulture, 32(1): 23-25.

Ghosh, S.N., Roy, S., Bera,B. 2013. Study on performance of twenty one guava cultivars in red and laterite soil of West Bengal under irrigated condition, Journal of Crop and Weed, 9(2): 81-83.

Kundu, S., Mitra SK. 1994. Studies on flowering and fruiting of Some Guava Cultivars in the Laterite Tract of West Bengal, Haryana Journal of Horticultural Sciences, 23(3): 213-218.

Milan, A. R. 2007. Breeding of Psidium species for root knot nematode resistance in Malaysia, Acta Horticulturae, 735: 61-69.

Ojha, A.P., Tiwari, J.P., Mishra, K.K. 1985. Studies on growth, flowering and yield of guava (Psidium guajava L.) cultivars under Tarai conditions of Uttar Pradesh, Progressive Horticulture, 17(1): 13-15.

Panse, V.C., Sukhatme, P.V. 1989. Statistical methods for Agricultural workers. Indian Council of Agricultural Research, New Delhi, pp. 199-210.

Rathore, D.S. 1976. Effect of season on growth and chemical composition of guava (Psidium guajava L.) fruits, Journal of Horticultural Sciences, 51: 41-47.

Reddy, Y.T.N., Kurien. R.M. 2008. Cumulative and residual effects of paclobutrazol on growth, yield and fruit quality of Alphonso mango, Journal of Horticulture Science, 3: 119-122.

Singh R., Sehgal, O. P. 1968. Studies on the blossom biology of Psidium guajava L. (guava) and pollen studies, stigmata receptivity, pollination and fruit set, Indian Journal of Horticulture, 25: 52-59.

\section{How to cite this article:}

Sahoo, J., R.K. Tarai, B.K. Sethy, A.K. Sahoo, S.C. Swain and Dash, D. 2017. Flowering and Fruiting Behaviour of Some Guava Genotypes under East and South East Coastal Plain Zone of Odisha. Int.J.Curr.Microbiol.App.Sci. 6(11): 3902-3911. doi: https://doi.org/10.20546/ijcmas.2017.611.456 